\title{
Choosing a textbook set as one of the problems of the contemporary Russian didactics
}

\section{[Vyber ucebniho souboru jako jeden z problemu soucasne didaktiky rustiny]}

\author{
Lenka Rozboudova - Jakub Konecny
}

\section{DOI: 10.18355/XL.2017.10.01.08}

\begin{abstract}
Abstrakt
V článku je nastíněn vývoj didaktiky ruského jazyka od počátku 90. let minulého století až do současnosti, přičemž na příkladu vztahu vyučujících ruského jazyka k učebnímu souboru, a to zejména při jeho výběru, je poukazováno na fakt, že současná didaktika ruštiny řeší otázky, které didaktikové západních jazyků řešili před zhruba 25 lety. $\mathrm{V}$ textu budou formulována kritéria, která by měla být při výběru učebního souboru respektována a zohledňována. Ta budou následně porovnána s odpověd'mi respondentů dotazníkového šetření.

Klíčová slova: učební soubor, ruština jako cizí jazyk, vyučující, didaktický prostředek, kritéria výběru učebního souboru
\end{abstract}

\section{Úvod}

Od poloviny 20. století do současnosti došlo ve vývoji didaktik cizích jazyků vyučovaných v československých a následně pak v českých školách k několika významným změnám. Chceme-li se v tomto článku zabývat učebnicemi jako jedním $\mathrm{z}$ témat didaktiky ruštiny jako cizího, či přesněji jako dalšího cizího jazyka, je třeba konstatovat, že právě zde se důsledky změn, v porovnání například s didaktikou angličtiny nebo němčiny, projevují relativně výrazně až do dnešní doby.

V období od 50. do 80. let minulého století byla ruština dominantním (a s výjimkou krátkého časového úseku v 60. letech v podstatě jediným) cizím jazykem vyučovaným v československých školách. Jako povinný cizí jazyk na základních i středních školách byla zavedena školským zákonem z roku 1948 a v této pozici zůstala až do roku 1989, kdy došlo k úpravám ve školském zákoně, které mimo jiné zavedly pluralismus v oblasti výuky cizích jazyků (srov. Průcha, 1999: 255).

K. Kostková a M. Píšová také zmiňují dominantní postavení ruštiny v období normalizace, zejména si však všímají vlivu této skutečnosti na vývoj didaktiky cizích jazyků jako celku. Do kontrastu s touto situací pak staví změny, které nastaly po roce 1989, kdy dokonce hovoří o „paradoxu domácího vývoje - zejména didaktiky západních jazyků sice usilovně obnovovaly síly jak v oblasti personálního zabezpečení oborů, tak v kontaktech se světem, zároveň však spolu s ostatními oborovými didaktikami na akademické scéně čelily ,anti-didaktickému“ trendu (...).“ (Stuchlikova - Janik, 2015: 88-89).

Nárys situace v oblasti didaktiky ruštiny v současnosti jako důsledek vývoje oboru po roce 1989

Když jsme výše zmínili důsledky změn, měli jsme na mysli zejména situaci vyvolanou porevolučním vývojem didaktik cizích jazyků. Zatímco didaktika angličtiny nebo němčiny prožívala $v$ určitém smyslu renesanci a všestranný rozvoj, didaktika ruštiny $\mathrm{v}$ podstatě zůstala stát na místě. Jedním $\mathrm{z}$ důvodů této stagnace byl zcela jistě okamžitý a téměř likvidační propad zájmu o výuku ruštiny na všech 
úrovních, který trval v podstatě celé desetiletín ${ }^{33}$ (srov. Průcha, 1999: 258). Mnozí vyučující ruštiny absolvovali kurzy angličtiny nebo němčiny a následně pak vyučovali tyto jazyky (a k výuce ruštiny se už bud' vůbec nevrátili, nebo se tak stalo až po pauze, která u mnohých trvala i více než 15 let). Je zcela pochopitelné, že v této situaci nedocházelo (a ani snad docházet nemohlo) k systematickému rozvoji didaktiky ruštiny. Dalším důvodem mohl být fakt, že před rokem 1989 byl tento obor (s ohledem na zaměření článku nebudeme rozlišovat metodiku od didaktiky, byt' jsme si vědomi zásadního rozdílu v podstatě obou pojetí i toho, že v období před rokem 1989 byla pěstována spíše prakticky orientovaná metodika, než teoretičtěji a vědečtěji zaměřená didaktika) na vysoké úrovni a celá řada poznatků tak mohla být využívána i nadále. Avšak to mohlo fungovat pouze omezenou dobu několika let (během kterých docházelo k etablování a rozvoji didaktik západních jazyků), po nichž bohužel $\mathrm{k}$ žádnému zlomu nedošlo.

Velmi výrazně jsou důsledky této stagnace zřetelné $\mathrm{v}$ oblasti personálního zabezpečení oboru dodnes. V době vzniku tohoto článku neexistuje jediná samostatná oborová rada didaktiky ruštiny jako cizího/dalšího cizího jazyka ${ }^{34}$, na žádném z rusistických pracovišt' fakult vzdělávajících učitele v České republice nepůsobí profesor nebo docent v oboru didaktika ruského jazyka. Další oblastí, ve které se důsledky vývoje projevují i v současné době, jsou právě učební texty, resp. otázka nabídky učebních souborů pro výuku ruštiny jako dalšího cizího jazyka na základních a středních školách v České republice a přístup vyučujících ruského jazyka k výběru a hodnocení učebnic. Jak bude uváděno dále $\mathrm{v}$ textu, zejména $\mathrm{v}$ této oblasti řeší obor problémy, s nimiž se didaktiky západních jazyků (zejm. pak didaktika angličtiny) potýkala v první polovině 90 . let minulého století.

I když z hlediska rozvoje oboru se didaktika ruštiny v českém prostředí od 90. let 20. století do současnosti výrazně neproměnila, bylo by chybou tvrdit, že její představitelé po celou tu dobu pouze udržovali předrevoluční stav. Situaci a problémy, které didaktika ruského jazyka řešila zejména v letech 1994-1999 popisují autoři publikace Didaktika ruského jazyka (Purm, Jelinek, Vesely, 2003: 236-243). $\mathrm{Na}$ teoretické úrovni byly řešeny zejména otázky výuky ruského jazyka v počáteční etapě žáků různého věku a s tím související problémy v oblasti motivace a pojetí výuky. Na úrovni praktické a aplikační, zejména v oblasti tvorby učebnic byli aktivní především odborníci $\mathrm{z}$ Katedry rusistiky a lingvodidaktiky Pedagogické fakulty Univerzity Karlovy v Praze.

Ačkoliv zájem o výuku ruštiny jako cizího jazyka na základních i středních školách v České republice klesl téměř na minimum (viz výše) ${ }^{35}$, vzhledem k tomu, že byly školy, v nichž se ruský jazyk stále vyučoval, byt' často jako volitelný předmět, bylo nezbytné nabídnout žákům i jejich vyučujícím nový a odpovídající učební soubor. V roce 1996 vydalo nakladatelství Fraus učební soubor Raduga (1. díl byl vydán v roce 1996, 2. díl v roce 1997 a 3. díl vznikl v roce 1999, vedoucím autorského kolektivu byl S. Jelínek). Tento učební soubor byl využíván ve výuce jak na základních, tak i na středních školách a až do roku 2002 se v podstatě jednalo o

\footnotetext{
${ }^{33}$ Ve školním roce 1993/94 si angličtinu jako cizí jazyk vybralo 42,3 \% žáků ZŠ, němčinu $55,4 \%$, francouzštinu $1,5 \%$ a ruštinu $0,1 \%$ (více žákủ měly dohromady další cizí jazyky, které byly v té době nabízeny). Ve školním roce 1996/97 byl poměr následující: $47 \%$ angličtina, 51,6 $\%$ němčina, $1,1 \%$ francouzština a $0,1 \%$ ruština. $V$ následujícím školním roce dochází $\mathrm{k}$ počátku dominance angličtiny, kterou si zvolilo 49,7 \% všech žáků základních škol, němčinu 49,1\%, francouzštinu $1 \%$. Ruštinu stále volí pouhá desetina všech žákủ základních škol.

${ }^{34} \mathrm{~V}$ roce 2016 získala Masarykova univerzita v Brně akreditaci doktorského studijního oboru Didaktika cizího jazyka - ruský jazyk, jehož realizace bude zahájena v roce 2017.

${ }^{35}$ J. Průcha (1999: 257) uvádí počet 760 žáků základních škol v celé České republice učících se ve školním roce 1997/98 ruský jazyk (tj. 0,1% všech žáků ZŠ; pro srovnání na Slovensku se jednalo o 7 \% žáků - 30.087).
} 
jediný existující titul. Vzhledem k tomu, že tento učební soubor byl zpracován pro střední a jazykové školy, vydalo nakladatelství Albra učební soubor Pojechali, jehož první díly byly určeny pro žáky základních škol ${ }^{36}$ a teprve vyšší díly byly vhodné pro středoškoláky (1. díl byl vydán v roce 2002, 2. díl v roce 2004, 3. díl v roce $2005,4$. díl v roce 2006, 5. díl v roce 2008 a závěrečný 6 . díl vyšel v roce 2011 ; v roce 2009 byl vydán ještě titul Pojechali Rychlý start - jedná se o propojení 1. a 2. dílu určené pro žáky, kteří s výukou začínají na 2. stupni ZŠ, vedoucí autorského kolektivu byla H. Žofková) $)^{37}$.

\section{Učební soubor jako jeden ze základních didaktických prostředků}

V odborné literatuře nalézáme celou řadu různých definic učebnice (učebního souboru). Např́íklad Z. Kalhous a O. Obst ji charakterizují např́íklad jako „konkretizaci projektu didaktického systému daného vyučovacího předmětu“. Při definici však záleží na tom, z jakého úhlu pohledu tento tradiční, avšak nezbytný didaktický prostředek nahlížíme. Učebnice totiž může být pojímána také jako „základní vyučovací a učební prostředek, který konkretizuje výchovné a vzdělávací cíle učebních osnov, vymezuje rozsah a obsah učiva a poskytuje podklady pro vypěstování intelektuálních a praktických dovedností, stanovených učebními osnovami.“ Nachází-li se v centru zájmu hledisko pedagogické komunikace, pak učebnice může být ,prostředek komunikace žáka (př́ip. i učitele) s učivem, a to prostředek komunikace zprostředkované." (Kalhous, Obst, 2002: 143)

Jinou definici učebnice nabízí J. Skalková (2007: 103-104), podle níž „učebnice představuje významnou etapu didaktické transformace kulturních obsahů do školního vzdělávání“, přičemž se jedná o „etapu, která se již př́ímo včleňuje do každodenní činnosti učitele a učení žáků při vyučování i mimo ně. (...) V průběhu vývoje se vytvořily různé přístupy $\mathrm{k}$ tvorbě učebnic. Promítají se do nich mimo jiné i didaktická východiska autorů. Podle Skalkové dochází k překonání tradičního chápání učebnice, která má sloužit $\mathrm{k}$ transmisi učiva v souladu s osnovami. Aktuálně je učebnice pojímána komplexně, což znamená, ,že bude nejen nositelem obsahu vzdělávání, ale také prostředkem řízení a učení žáků, založeného na jejich vlastní aktivní činnosti“. Zejména tento přístup je velmi důležitý v didaktice cizích jazyků, nebot' jazyk učebnice (tj. způsob, jakým komunikuje s žáky) se stává jedním z nejvýznamnějších hledisek jejího hodnocení.

Učebnice podle J. Průchy (2005: 272) může laikovi připadat jako „kterákoliv běžná knížka - má nějaký text a k tomu obrázky (...). Ve skutečnosti je dobře zpracovaná školní učebnice velmi důmyslné médium, s bohatě členěnou strukturou a s velmi funkčně konstruovanými komponenty této struktury“.

Vedle obecně-didaktických definic učebnice bychom pro úplnost rádi uvedli ještě dvě definice oborově-didaktické. S. Jelínek (1994-1995: 83) ji charakterizuje jako „model, v němž se obráží (zřejmě odráží) určitá koncepce cizojazyčné výuky, jako jádro výukového programu, jako zobecněný program součinnosti učitele a žáků, jako invariantní konspekt učebního kursu aj“.

Jinou definici nalezneme v publikaci Jak napsat mezikulturni učebnici ruštiny jako cizího jazyka ${ }^{38}$ autorů A. L. Berdičevského a A. V. Golubevové (2015:

\footnotetext{
${ }^{36}$ Učební soubor Pojechali byl v závislosti na tehdy platnou legislativu původně koncipován jako soubor pro výuku ruštiny jako prvního cizího jazyka, čemuž i odpovídá jeho koncepce, která zohledňovala specifika výuky cizího jazyka na prvním stupni základní školy.

${ }^{37}$ V letech 2007-2011 byl postupně vydán inovovaný učební soubor Raduga po-novomu (S. Jelínek a kol.), na trhu se objevují také další učební soubory (podrobněji k této problematice viz např́íklad Konečný, 2013; 2016), jejich popis však není předmětem našeho článku. V tomto odstavci jsme chtěli pouze naznačit situaci, která panovala v oboru v 90. letech 20. století.

${ }^{38}$ Как написать межкультурный учебник русского языка как иностранного
} 
19). Její autorkou je S. K. Miloslavská, podle níž je současná učebnice pojímána jako velmi důležitý nástroj a jako vedoucí prostředek vzdělávání, který maximálně komplexně realizuje rysy konkrétního metodického systému, je chápán jako jeho informační model a slouží cílům automatizace řízení pedagogického procesu. Kromě toho je ve svých objektových i subjektových vlastnostech učebnice jakéhokoliv cizího jazyka (tedy i jazyka ruského) schopna stát se organickým prostředkem nejen utváření, ale i fixace určitého pojetí cílové země a národa vnějším světem. ${ }^{39}$

Jak vyplývá z výše uvedených definic, má učebnice nejen celou řadu funkcí, ale je třeba mít vždy na paměti její dvě skupiny uživatelů. První skupinu představují žáci, kteří se z nich učí, druhou skupinou jsou učitelé, pro něž jsou dle realizovaných výzkumů jedním z hlavních zdrojů při plánování výuky (srov. Prucha, 2005: 293).

H. Žofková (1989: 161) rozlišuje ve vztahu učitel - učebnice dva protichůdné př́istupy. Podle zastánců prvního př́istupu učebnice nemá sloužit jako hlavní řídící článek výuky, protože ve vyučovacím procesu existuje celá řada proměnných, a proto je hlavní role ve vyučovacím procesu přisuzována tvưrčí činnosti učitele. Naproti tomu zastánci druhého př́stupu považují učebnici za základ jazykové výuky, který „výrazně určuje její pojetí a celkový postup, a proto by učitel neměl libovolně a neuváženě zasahovat do posloupnosti jednotlivých kroků“. Přístup každého autorského kolektivu k tomuto základnímu vztahu se následně promítá i do celkové koncepce jejich učebních souborů.

Domníváme se, že vztah učitele k učebnici by neměl být absolutní a extrémní (tj. nacházet se na jedné nebo druhé hranici). Jak zdůrazňuje i H. Žofková (1989: 161), závisí způsob práce učitele s učebnicí mimo jiné na jejím celkovém pojetí a metodickém zpracování.

V souladu s výše uvedeným tak způsob, jakým bude učitel $\mathrm{k}$ učebnici přistupovat, předpokládá, že se ještě před vlastním pořízením tohoto didaktického prostředku vyučující podrobně seznámí se všemi částmi učebního souboru a bude schopen (což s ohledem na jeho kvalifikaci považujeme za samozřejmý předpoklad) a zejména ochoten věnovat tomuto kroku čas a energii. Jedině tak se totiž může seznámit s autorskou i didaktickou koncepcí učebního souboru, zjistit, zda daný učební soubor bude vyhovovat jemu a na základě znalosti svých žákủ také předvídat, zda i pro ně bude zvolený materiál vhodný a uživatelsky přátelský.

Zejména s ohledem na požadavek na individualizaci vyučovacího procesu se tento požadavek jeví jako velmi aktuální, nebot', jak již před téměř dvaceti lety uváděl R. Purm (1998: 111) ,jde tedy o učebnici cizího jazyka, která by umožňovala žákům či studentům používat takové postupy při osvojování příslušného jazykového materiálu a při formování komunikativní kompetence v př́slušných druzích cizojazyčné řečové činnosti, které by odpovídaly jejich poznávacím stylům a učebním strategiím“. Ačkoliv si i sám autor zmíněného požadavku uvědomoval problematičnost důsledné realizace tohoto požadavku v učebnicích, jsme toho názoru, že promyšlenou didaktickou koncepcí, vhodným zpracováním obsahu a také kvalitním grafickým, typografickým i řemeslným zpracováním celého učebního souboru lze dosáhnout takové míry různosti, která dostatečným způsobem požadavek na individualizaci zajistí.

\footnotetext{
${ }^{39}$ «Современный учебник рассматривается как важнейший инструмент и как ведущее средство образования, которое наиболее полно воплощает черты определённой методической системы, понимается как её информационная модель и служит целям автоматизации управления педагогическим процессом. Кроме того, в своём объектном и субъектном качестве учебник любого иностранного языка, в том числе и русского, способен быть органичным средством не только формирования, но и укоренения определённого образа соответствующей страны и народа во внешнем мире».
}

73

XLinguae Journal, Volume 10 Issue 1, January 2017, ISSN 1337-8384 
Ještě než se $\mathrm{v}$ další části textu budeme věnovat problematice výběru učebního souboru pro výuku ruštiny jako dalšího cizího jazyka v českých základních a středních školách, navážeme na dříve formulované tvrzení, že právě oblast učebnic pro výuku ruštiny je jednou z oblastí, v níž se výrazně projevuje odskok české didaktiky ruského jazyka od didaktik západních jazyků. I. Pýchová publikovala již na začátku 90. let v časopise Cizí jazyky článek Móda a učebnice cizích jazyků, v němž se věnuje problematice výběru zahraničních učebnic cizích jazyků pro výuku $\mathrm{v}$ českých školách, přičemž si všímá zejména vlivu módy na rozhodování učitelů při výběru. Ve svém článku se autorka zabývá zejména učebními soubory pro výuku angličtiny a francouzštiny, analyzuje možné klady i zápory jednotlivých zahraničních učebních souborů a v závěru pak formuluje několik kritérií evaluace kvality učebnic cizích jazyků, jejichž platnost dle našeho názoru přetrvává do současnosti (srov. Pychova, 1993-1994: 104-109).

O důležitosti otázky výběru učebnic cizího jazyka pro didaktiky západních jazyků v období první poloviny 90 . let svědčí i další články publikované v časopise Cizí jazyky. Například svůj úvodník k číslu 3-4 nazval J. Hendrich Rozlišujme pozorně a důsledně a čtenáře v něm upozorňuje mj. na skutečnost, že „zdaleka ne každá učebnice, která se objevuje na knižním trhu, neustále zásobovaném novými domácími i zahraničními tituly, splňuje alespoň základní požadavky na vyhovující učebnici kladené. (...) Nutnost bedlivě zvažovat klady a zápory učebních materiálů, rozlišovat rysy podstatné od podružných na základě jejich důkladné znalosti před volbou, to vyplývá zvlášt' výrazně z dnešních, dřive nebývalých možností učitelových (...)“(Hendrich, 1993-1994: 81-82).

Z předcházejících odstavců jednoznačně vyplývá, že zatímco před učiteli západních jazyků se těsně po revoluci objevila nová výzva spočívající ve výběru vhodných učebních souborů pro výuku těchto jazyků, hrstka učitelů ruského jazyka, která i v období 90 . let pokračovala ve výuce ruštiny jako cizího jazyka řešila až do roku 1996, kdy byl vydán první díl učebního souboru Raduga, neexistenci žádného vhodného titulu pro výuku.

S narůstajícím zájmem žáků o ruský jazyk (zejména i ve vztahu k zavedení povinné výuky dalšího cizího jazyka nejpozději od 8. ročníku základní školy od školního roku 2013/2014) ${ }^{40}$ se nyní, po dvou desetiletích, dostávají i učitelé ruského jazyka do pozice svých kolegů a s narůstající nabídkou učebních souborů jsou na ně kladeny také nové požadavky a úkoly spočívající zejména v analýze, hodnocení a výběru vhodných učebních souborů i dalších výukových materiálů.

$\mathrm{Na}$ rozdíl od výuky angličtiny, němčiny nebo francouzštiny, pro výuku ruského jazyka $\mathrm{v}$ českém prostředí nikdy nebyly a ani dnes prakticky nejsou využívány učební soubory vzniklé v zahraničí. Hlavním důvodem je specifické postavení ruštiny jako cizího jazyka vyučované v zemi, kde je mateřským jazykem žáků jiný slovanský jazyk. Tato situace zcela potvrzuje názor L. Housky (1994-1995: 271), že ,jeden zásadní nedostatek bude ovšem mít každá učebnice vzniklá v zemi výchozího jazyka a adresovaná uživatelům tohoto jazyka jako cizího jazyka

\footnotetext{
${ }^{40}$ Podle přehledu Statistické ročenky školství: výkonové ukazatele (online) se ve školním roce 2011/2012 v celé ČR učilo na základní škole ruský jazyk 25.512 žáků (z toho 15.543 v rámci povinného předmětu), ve školním roce 2012/2013 to bylo 26.194 žáků (z toho $15.533 \mathrm{v}$ rámci povinného předmětu), ve školním roce 2013/2014 se jednalo o 41.538 žáků (z toho 41.155 žáků si ruštinu zvolilo jako povinný další cizí jazyk, 206 jako první cizí jazyk a 177 jako nepovinný předmět). Zájem o výuku ruského jazyka na úrovni základního vzdělávání dále roste, ve školním roce 2014/2015 se rusky učilo 51.689 žákủ (z toho 51.157 povinně jako další cizí jazyk, 270 jako první cizí jazyk a 262 jako nepovinný předmět). Nepatrný pokles nastal v minulém školním roce (2015/2016), kdy se rusky učilo 50.943 žáků základních škol (povinně jako další cizí jazyk 50.367, povinně jako první cizí jazyk 385 a jako volitelný předmět si ruštinu vybralo 191 žáků ZŠ na celém území ČR)
} 
v zahraničí: nikdy nemůže respektovat potřebu žáka v konkrétní jazykové oblasti, at' již jde o otázky konfrontativní, kontrastivní či v oblasti interference, ale i další“. I z tohoto důvodu se na českém trhu objevují a využití nalézají zejména domácí učební soubory, vždy zpracované autorským kolektivem složeným jak z rodilých mluvčích českého, tak i ruského jazyka.

Ačkoliv jsme si vědomi, že výše uvedené otázky a problémy současné české didaktiky ruštiny jako cizího i dalšího cizího jazyka lze nahlížet z mnoha dalších úhlů pohledu, považujeme zde představený exkurz do historie i současnosti za dostatečný, nebot' hlavním smyslem této části našeho článku bylo vymezit zkoumanou problematiku a poukázat na vybrané problémy, s nimiž se v současné době didaktikové i učitelé ruského jazyka potýkají. Následující text bude věnován interpretaci výsledků dotazníkového šetření, jehož respondenty se stali učitelé ruského jazyka a které bylo zaměřené na jejich vztah k učebnicím ruského jazyka a otázce výběru.

\section{Výběr učebního souboru pro výuku ruského jazyka na základních a středních školách}

Jak již bylo uvedeno výše, stále se rozšiřující nabídka učebních souborů klade nyní i před učitele ruského jazyka úkol zodpovědného výběru nejvhodnějšího učebního souboru, který bude nejvíce vyhovovat dané skupině žáků, ale i samotnému učiteli. Aby se učební soubor mohl stát účinným pomocníkem v procesu učení se cizímu jazyku, musí být jeho výběr proveden velmi zodpovědně po pečlivém zvážení mnohých kritérií.

Odborných textů, zabývajících se problematikou výběru učebnic v obecné rovině nebo se zaměřením na cizí jazyky můžeme najít poměrně velké množství, viz například již výše uvedené statě či mnohé další, např̀. kapitola M. Nogové Hodnotenie kvality učebníc v súlade s novým kurikulom v kolektivní monografii P. Knechta, T. Janíka a kol. (2008: 37-52), dále publikace Z. Sikorové (2004), J. Maňáka a D. Klapka (2006), J. Maňáka a P. Knechta (2007), avšak problematika výběru učebnic ruského jazyka jako jazyka cizího v současném českém školním prostředí zpracována dosud nebyla.

Vzhledem k výše nastíněné situaci v oblasti výuky ruského jazyka v České republice jsme se stanovili kritéria hodnocení a výběru učebních souborủ pro výuku ruského jazyka na českých základních a středních školách, která jednak odpovídají obecným požadavkům pro evaluaci učebnic, jednak reflektují současné potřeby plynoucí z postavení ruského jazyka v českém vzdělávacím systému, který je v současné době vyučován zpravidla jako druhý, př́ípadně i třetí cizí jazyk. Dále jsme rovněž vycházeli ze současných poznatků didaktiky ruského jazyka jako jazyka cizího.

Stanovili jsme si tedy následujících 11 oblastí hodnocení učebních souborů, přičemž mnohá z nich jsou platná i pro všechny ostatní cizí jazyky. Jsme si vědomi, že tento výčet jistě není vyčerpávající a bylo by možné najít i další relevantní kritéria v závislosti na žákovské skupině, požadavcích praxe, aj.

\section{Soulad s platnými kurikulárními a legislativními dokumenty}

Ačkoli zastáváme názor, že výuka cizího jazyka by měla primárně směřovat $\mathrm{k}$ uplatnění jazyka v praxi, tedy v soukromém nebo pracovním životě žáka, nikoli $\mathrm{k}$ úspěšnému složení maturitní či jiné certifikované zkoušky, vzhledem k institucionální formě školního vzdělávání shledáváme prvním a zároveň zásadním kritériem pro volbu učebního souboru jeho soulad se všemi požadavky, které jsou kladeny na výuku ruského jazyka na daném stupni, je proto nezbytně nutné respektovat požadavky stanovené platnými Rámcovými vzdělávacími programy, př́padně i dalšími kurikulárními a legislativními dokumenty, jedná se nejen o výstupní úrovně ovládání 
jazyka, ale i o otázky cílů, klíčových kompetencí, očekávaných výstupů, výchovy k toleranci, demokracii či osobní odpovědnosti, genderové vyváženosti a mnoho dalších.

V př́ípadě ruského jazyka jako dalšího cizího jazyka je dle RVP nutné, aby po zvládnutí učebního souboru žák dosáhl komunikativní kompetence na úrovni A1 v př́ípadě základní školy a na úrovni B1 dle Společného evropského referenčního rámce pro jazyky v př́ípadě střední školy.

Významným požadavkem plynoucím z RVP je rovněž realizace mezipředmětových vztahů. Výuka cizích jazyků, a tedy i jazyka ruského, nabízí široké pole možností pro uplatňování tohoto přístupu. Učební soubor by tedy měl obsahovat takový materiál, který v sobě mezipředmětové přesahy implikuje a napomáhá tak nejen pochopení vztahů ruského jazyka k jiným cizím jazykům či $\mathrm{k}$ jazyku mateřskému, ale i zasazení ruského jazyka a s ním spojené ruské kultury do širších společenských souvislostí.

Soulad s kurikulárními a legislativními dokumenty platnými v ČR je rovněž jedním z hlavních kritérií pro hodnocení učebních souborů $\mathrm{k}$ udělení schvalovací doložky Ministerstva školství mládeže a tělovýchovy ${ }^{41}$, proto by učitel měl při svém výběru udělení, respektive neudělení schvalovací doložky MŠMT považovat za významný ukazatel prijiatelnosti souboru.

\section{Didaktická koncepce učebního souboru}

Z hlediska obsahu považujeme za zásadní vhodně zvolenou didaktickou koncepci celého učebního souboru, která prostupuje celým učebním souborem a která se promítá do jejího obsahového i formálního uspořádání jednotlivých komponentů, tj. textů, cvičení, ilustrací, doplňkových materiálů a dalších, nejzřetelněji je pak patrná v uspořádání jednotlivých lekcí. Za velmi podstatné považujeme jednak vyváženost učebního souboru, tj. proporcionalitu zastoupení materiálů pro nácvik všech jazykových prostředků i řečových dovedností, jednak jejich systematičnost a přehlednost zpracování. Dle S. Jelínka (1994-1995: 85) by v didaktické koncepci „měly být bezprostředně zakotveny předpoklady pro variabilitu vyučovacích postupư“, nebot’ nelze v učebnici nabízený model práce považovat za jediný možný či univerzální, navíc proces cizojazyčné výuky musí být dle současných požadavků přizpůsobován individuálním potřebám prríslušné žákovské skupiny či dokonce jednotlivých žáků. Tento požadavek variability se však v žádném případě nevylučuje s požadavkem na systematičnost, soustavnost, uspořádanost a přehlednost. Jak potvrdilo i naše šetření níže, tyto jednotlivé ukazatele považují i samotní učitelé za zásadní pro výběr učebního souboru.

Didaktická koncepce představuje základní východisko pro efektivní práci s daným učebním souborem, měla by tedy být uživateli-učiteli zcela jasná, a proto by v metodické př́ručce $\mathrm{k}$ učebnímu souboru mělo být $\mathrm{k}$ dispozici vysvětlení jeho základní didaktické koncepce, jakož i základní rámcové pokyny pro práci s ním.

\section{Součásti učebního souboru a doplňkové materiály}

Současné moderní učebnice pro výuku cizích jazyků nejen na základních a středních školách nejsou již několik desetiletí pouhou jedinou učebnicí, vždy představují celý učební soubor několika (a někdy i mnoha) komponentů v různých kombinacích - učebnice pro žáky, učebnice pro učitele, pracovní sešit, metodická

\footnotetext{
${ }^{41}$ Směrnice náměstka ministra pro vzdělávání ministerstva školství, mládeže a tělovýchovy $\mathrm{k}$ postupu a stanoveným podmínkám pro udělování a odnímání schvalovacích doložek učebnicím a učebním textům a k zařazování učebnic a učebních textů do seznamu učebnic, č. j. MSMT$34616 / 2013$.
} 
příručka, zvuková nahrávka, videomateriály, elektronické materiály či elektronická podpora, písanky, čítanky, zpěvníky, hry a další, které jsou funkčně propojeny a vzájemně se doplňují. Učitel by měl zhodnotit nejen pouhou existenci jednotlivých komponent, ale především jejich kvalitu, funkčnost a vzájemnou provázanost. Význam jednotlivých součástí nelze zpochybňovat, avšak podrobněji níže uvádíme pouze několik poznámek $\mathrm{k}$ metodické príručce a elektronické podpoře.

Z pohledu kvalitní realizace výukového procesu považujeme za velmi důležitou součást souboru zejména kvalitně zpracovanou metodickou př́ručku, která by neměla přinášet pouze úzce zaměřené prakticky orientované návody a doporučení k jednotlivým lekcím, či dokonce jednotlivým textům a cvičením, ale měla by spíše naznačovat možnosti práce $\mathrm{s}$ daným materiálem, komentáře $\mathrm{k}$ jeho implementaci $\mathrm{v}$ určitých podmínkách s ohledem na vhodnost a efektivitu, př́ípadně i upozornění na úskalí jeho užití. Bohužel je ale nutno konstatovat, že metodické příručky k některým učebním souborům pro výuku ruského jazyka tento požadavek ani zdaleka nesplňují, přináší pouze velmi obecné informace o výuce ruského jazyka, př́ípadně klíč k některým cvičením, avšak jakákoli konkrétnější metodická podpora chybí. Je zjevné, že takto koncipované metodické příručky jsou vytvářeny pouze účelově, aby tato dnes již zcela běžná součást učebních souborů formálně nechyběla.

V kontextu současných požadavků na samotnou realizaci výuky, kdy jsou mnozí učitelé dokonce proti své vůli nuceni využívat informační a komunikační technologie ve svých předmětech, považujeme za důležité hledisko také existenci elektronické podpory souboru, at' už se jedná o interaktivní verze učebnic, doplňkové materiály v elektronické podobě na CD-ROMu nebo ke stažení z webu vydavatelství či jinou možnost. Pokud učební soubor disponuje kvalitní a funkční elektronickou podporou, může být významným pomocníkem nejen pro práci učitele v hodinách ruského jazyka, ale i samotných žáků při jejich samostatné domácí přípravě, jakož i mohou významně přispět ke zvýšení motivace a zájmu o ruský jazyk žáků.

\section{Jazykové prostředky a řečové dovednosti}

Jak jsme již uvedli výše v souvislosti s koncepcí učebního souboru, je nutné vždy velmi pečlivě zhodnotit proporcionalitu zastoupení všech jazykových prostředků i řečových dovedností. Jsme si vědomi, že různé skupiny žáků mohou dle svých zájmů či plánované sféry vlastního praktického užívání cizího jazyka mít v tomto ohledu jisté preference (zejména při učení se druhému nebo dokonce třetímu cizímu jazyku), nicméně kvalitní výukový materiál by neměl ani jeden aspekt jazyka, jakož ani jednu $\mathrm{z}$ řečových dovedností opomíjet, zvláště pak v př́ípadě, že bude daný učební soubor využíván na základní či na všeobecně vzdělávací stř̌ední škole. Zejména by se pak učitel měl zaměřit na zpo̊sob práce se zvukovou stránkou jazyka, která bývá v učebnicích velmi často podceňována, bývá zpravidla situována ve větším rozsahu pouze do prvního dílu souboru a $\mathrm{v}$ dalších dílech je pak zvukové stránce věnováno pouze minimum prostoru (podrobněji o tomto Konečný: 2012 a Konečný: 2013a), což rozhodně nelze považovat za dostačující.

Z hlediska jazykových prostředků je třeba si při výběru zodpovědět řadu klíčových otázek: Jakým způsobem jsou jazykové prostředky prezentovány? Je důraz kladen na indukci nebo dedukci při uvádění nového jazykového materiálu? Odpovídá způsob prezentace i procvičování jazykového materiálu stupni kognitivního vývoje a jazykové úrovni žáků? Je zachováván princip jedné obtížnosti? Je uplatňován zřetel k mateřštině, a pokud ano, je zpracován pouze implicitně nebo i explicitně? Nabízí soubor dostatečné množství různorodých cvičení, která jsou uspořádána do logických sekvencí od čistě jazykových až po komunikativní? Je zpracování jazykového materiálu v učebním souboru systematické a cyklicky se opakující? Je práce s jazykovými prostředky založena na integrativním principu učení se jazykovým prostředkům? Výčet těchto otázek jistě není vyčerpávající a jistě by se našly i další 
zásadní otázky vzhledem ke konkrétní žákovské skupině, nicméně minimálně nad těmito by se učitel při výběru učebnice měl zamýšlet.

Komunikativní zaměření cizojazyčné výuky je v současné době nezpochybnitelným požadavkem vyplývajícím ze všech platných klíčových kurikulárních dokumentů, proto i všechny v současné době nabízené učební soubory pro ruský jazyk deklarují komunikativnost. Je však nutné si podrobněji analyzovat, jak autoři př́slušného učebního souboru deklarovanou komunikativnost chápou a zda ji neztotožňují s pouhou konverzací, ale naopak koncipují celý soubor k rozvoji všech řečových dovedností. Je tedy nutno si položit otázku, zda soubor nabízí dostatek cvičení a úkolů k formování dovedností nejen vústním projevu, ale také v samostatném písemném projevu (který však není zaměňován s pouhou technikou psaní), čtení a poslechu s porozuměním. Nutno také podotknout, že učební soubor by měl rozvíjet komunikativní kompetenci ve všech jejích aspektech, tedy nejen čistě jazykovém, ale je třeba mít na paměti, že by měla být uplatňována i hlediska sociolingvistická a pragmatická (SERRJ, 2002: 13).

Důležitou roli ve vztahu $\mathrm{k}$ tomuto kritériu hraje také orientace na reálnou komunikaci a situace, do nichž se mohou žáci příslušného věku dostat a které mohou na své jazykové úrovni řešit. Vhodná volba jazykových prostředků a způsob rozvoje řečových dovedností ve vztahu k reálným situacím působí také jako výrazný motivační faktor.

\section{Výukové texty}

Důležitou složkou každého učebního souboru je jeho textová část, která by měla být stimulem a zároveň prostředkem pro rozvoj jednotlivých řečových dovedností i fixaci jazykových prostředků. Různorodost, autentičnost, přiměřenost a zajímavost textů pro žáka považujeme za nejdůležitější předpoklady kvalitního rozvoje komunikativní kompetence. Pouze v př́padě, že cizojazyčný text splňuje tato kritéria, může se stát efektivním stimulem a motivačním prvkem nejen k produkci vlastních textů, ale i k percepci textů v cizím jazyce.

Vzhledem $\mathrm{k}$ tomu, že považujeme text za klíčový prostředek v procesu učení se cizímu jazyku, domníváme se, že učební soubor by měl disponovat co možná nejširší škálou různorodých textů $\mathrm{v}$ nejširším slova smyslu, které budou sloužit nejen $\mathrm{k}$ rozvoji poslechu a čtení s porozuměním, ale které budou rovněž sloužit jako výchozí impuls pro ústní i písemný projev a také budou prostředkem prezentace, soustředěného nácviku i opakování jazykových prostředků.

Jsme si vědomi, že základní učebnice pro žáka nemůže být texty přehlcena, proto považujeme za nutné, aby učební soubor nabízel další doplňkové texty, které mohou být $\mathrm{k}$ dispozici $\mathrm{v}$ pracovním sešitě, metodické příručce, doplňkových publikacích jako např́klad $\mathrm{v}$ čítance či $\mathrm{v}$ rámci elektronické podpory učebního souboru. Domníváme se, že tyto texty však nutně nemusí být didaktizovány, jejich využití a didaktická transformace může být ponechána na učiteli a jeho didaktické invenci v závislosti na potřebách konkrétní žákovské skupiny. Tyto texty by však rozhodně měly být ve všech ohledech přiměřené dané žákovské skupině a jejich jazyk by měl být autentický a zároveň odpovídající aktuální normě ruského jazyka.

\section{Jazyková a věcná správnost}

Dalším významným ukazatelem kvality učebního souboru je bezesporu také jeho jazyková a věcná správnost. Jazyk by měl být zcela v souladu s aktuálně platnými jazykovými normami, byt' nevylučujeme užití např́iklad hovorových výrazů pro demonstraci reálné komunikace, které však musí být v metodické příručce řádně okomentováno. 
Vzhledem k tomu, že učebnice pracuje nejen s jazykovými fakty, ale i fakty extralingvistickými, nejčastěji v podobě reálií a lingvoreálií, je nezbytně nutné, aby uváděné poznatky byly vždy v souladu s aktuálním objektivním stavem reality. Nelze opomíjet ani správnost lingvistickou, čímž máme na mysli správnost užívané lingvistické terminologie a uváděných jazykových vztahů.

\section{Zř̌tel $k$ češtině jako mateřskému jazyku většiny žáků}

Vzhledem k tomu, že pokud se učíme blízce př́ibuzný jazyk, jsme daleko více ovlivňováni jazykem mateřským, než v př́padě nepříbuzného jazyka. V naší situaci, tedy učení se ruštině v českém prostředí proto nutně musíme počítat $\mathrm{s}$ tím, že některé jevy budou silně zasaženy interferencí a zároveň jiné jevy ani není nutné př́liš vysvětlovat či nacvičovat, nebot' fungují v mateřském jazyce stejně či obdobně, hledisko zřetele $\mathrm{k}$ mateřštině považujeme tedy pro výběr souboru pro výuku ruského jazyka v českých základních a středních školách za zásadní. Tento faktor je dle našeho názoru prŕčinou toho, že na českém trhu výrazně převažuje nabídka učebních souborů, jejichž autorský kolektiv je smíšeným kolektivem odborníků-Čechů a rodilých mluvčích, tedy že učební soubory ruské provenience nejsou na trhu př́liš žádané, a tedy ani běžně dostupné, zejména pak v menších městech.

Lze konstatovat, že všechny v českých školách $\mathrm{k}$ výuce běžně používané soubory určitým zpo̊sobem zřetel k češtině jako mateřštině většiny žáků zohledňují, avšak různými způsoby, některé tituly preferují pouze implicitní př́stup, v jiných je žák systematicky explicitně veden k porovnávání jazykových jevů v ruštině a češtině. Dle našeho názoru by kvalitní soubor měl funkčně pracovat s oběma přístupy.

\section{Zř̌tel $\mathbf{k}$ uživatelům}

Jak už bylo uvedeno výše, učební soubor by měl být př́ivětivý, srozumitelný a přehledný pro své uživatele, tedy nejen pro učitele, ale hlavně pro žáky. Při výběru souboru by měl učitel zvážit nejen to, zda jemu samotnému styl a koncepce souboru vyhovuje, ale zejména to, zda bude vyhovovat jeho žákům, zda pro ně přináší zajímavé impulsy ke komunikaci, zda je jim všestranně přiměřený a jak k žákům promlouvá. Obsah učebnice by měl být vždy pro žáky motivující a měl by rozvíjet nejen jejich komunikativní kompetenci, ale i všechny ostatní klíčové kompetence stanovené Rámcovými vzdělávacími programy, jakož i vhodně formovat jejich postoje a hodnotovou orientaci.

Význam motivačních prvků k učení se ruštině, které učebnice nabízí, je pro kontext výuky ruského jazyka jako druhého nebo dokonce třetího jazyka v českých školách zásadní, pokud tyto prvky učebnice nenabízí, závisí veškerá motivace na učiteli a pokud mu v tomto ohledu učební soubor nijak nepomáhá, může být neustálé zajištování motivace žáků k učení se ruštině velmi obtížné.

\section{Diferenciace učiva}

Princip diferenciace učiva není ničím zcela novým, avšak tento princip nabírá v posledních letech na významu nejen s ohledem na inkluzivní vzdělávání, které vešlo v platnost od školního roku 2016/2017, nebo ve vztahu k žákům-cizincům, jejichž počty jsou $\mathrm{v}$ českých školách již nezanedbatelné. Zohledňování žáků s nejrůznějšími speciálními vzdělávacími potřebami je v současné době již normou, proto by učební soubor měl být i pro tyto žáky přivětivý a srozumitelný a nabízet různorodé možnosti, jak dosáhnout stanovených vzdělávacích cílů, učební soubor by tedy měl efektivně pomáhat učiteli i samotným žákům.

Soubor by měl nabízet nejen různorodá cvičení k podpoře práce těchto žáků, ale i grafická struktura souboru by měla odpovídat jejich potřebám. Zejména v prrípadě ruského jazyka je nutno se vyvarovat užívání mnohých fontů písma či 
kurzívy, která činí obtíže žákům obecně, rovněž přílišná podbarvenost textů, skosení textů, hustota textu na stránce apod. mohou představovat pro žáky se speciálními vzdělávacími potřebami značné obtíže, zvláště pak v ruském jazyce.

\section{Formální a grafické zpracování}

Výše uvedená kritéria a zejména pak zřetel $\mathrm{k}$ uživatelům a diferenciace učiva jsou do značné míry závislá na formálním a grafickém zpracování souboru, máme na mysli celkovou jednotnou koncepci grafických prvků, způsob grafické diferenciace učiva, kvalitu ilustračních materiálů, obrázků a fotografií, které odpovídají věku žáků, jakož i základní řemeslné zpracování učebnice, oddělení či integraci pracovního sešitu a učebnice, elektronickou či tištěnou formu dalších komponent souboru, apod. Zde nutno konstatovat, že učitel by neměl podléhat prvnímu dojmu, na který silně působí především právě velmi přitažlivé formální a grafické zpracování, protože obsahová kvalita učebního souboru ne vždy koresponduje s kvalitou formálního ztvárnění.

\section{Dostupnost}

Posledním hlediskem, které však nelze považovat při výběru za bezvýznamné, je obecná dostupnost a cena učebnice, nebot' finanční náročnost souboru může být důvodem pro jeho odmítnutí bud' vedením škol, které učebnice pro své žáky pořizují, nebo samotnými rodiči žáků. Pozor je třeba dávat zejména $\mathrm{v}$ př́padě reedic a několikerých vydání souborů, které někdy vzájemně nekorespondují.

\section{Výsledky dotazníkového průzkumu mezi učiteli ruského jazyka}

Vzhledem $\mathrm{k}$ tomu, že výběr učebního souboru pro výuku cizích jazyků na základních a středních školách mnohdy zcela závisí na samotném učiteli, respektive na konsenzu předmětové komise pro daný cizí jazyk, zajímalo nás, podle jakého klíče zvolili učitelé učební soubor pro výuku ruského jazyka, s nímž ve své praxi pracují a které charakteristiky učebnic považují při výběru za klíčové.

Dotazování se zúčastnilo celkem 96 učitelů působících na středních, základních a jiných typech škol. Anonymní dotazování probíhalo průběžně od března 2015 do záŕí 2016 v rámci vzdělávacích akcí dalšího vzdělávání pedagogických pracovníků v Praze, Brně a Ostravě pořádaných Katedrou rusistiky a lingvodidaktiky PedF UK. Kromě otázky zjištující znalost konkrétních učebních souborů byly všechny otázky formulované jako otevřené, abychom jednotlivými distraktory nijak neovlivňovali odpovědi respondentů, byt' právě otevřenost otázek byla často důvodem nutného vyloučení některých odpovědí kvưli nerelevanci odpovědi.

První otázka zjištovala, které učební soubory, jež jsou dostupné na českém trhu, učitelé znají, z nabídky mohli respondenti vybírat neomezené množství titulů a zároveň mohli uvést ještě další soubory. $Z$ odpovědí vyplynulo, že učitelé běžně dostupné učební soubory znají, nejčastěji uváděli, že znají učební soubory Raduga ponovomu $\left(95 \%{ }^{42}\right)$, Pojechali! ( $89 \%$ ) a Klass! (84 \%), což koresponduje i s odpověd'mi na následující otázku, která zjištovala, které soubory učitelé použivají ve své výukové praxi jako hlavní a které jako zdroj doplňkových materiálů. Další soubory uváděli respondenti již menší rozsahu, Vremena uvedlo 59 \%, Echo 30 \%, Klassnyje druzja $28 \%$ respondentů.

\footnotetext{
${ }^{42}$ Procenta jsou vždy zaokrouhlena na celé číslo.
} 


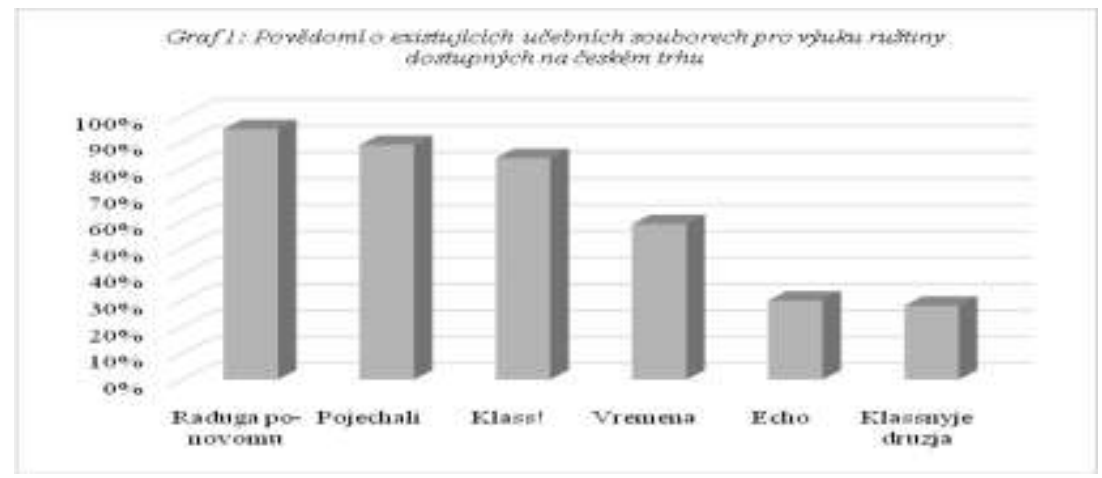

Jako hlavní učební soubor využívají 52 učitelé (54\%) soubor Raduga ponovomu, 19 učitelů (20\%) Klass!, 14 učitelů (15\%) Pojechali! a 11 učitelů (11\%) Ruština nejen pro samouky ${ }^{43}$. Jako zdroj doplňkových materiálů uváděli učitelé nejčastěji internet - $21 \%$ dotázaných, dále nejčastěji učitelé uváděli publikace k prŕípravě na maturitní zkoušku od nakladatelství Infoa Ruština - maturitní príprava a Ruština - otázky a odpovédi nejen k maturitě - $15 \%$ respondentü ${ }^{44}$ a dále v menší četnosti prakticky všechny na českém trhu dostupné učební soubory i jiné materiály $\mathrm{k}$ výuce ruského jazyka.

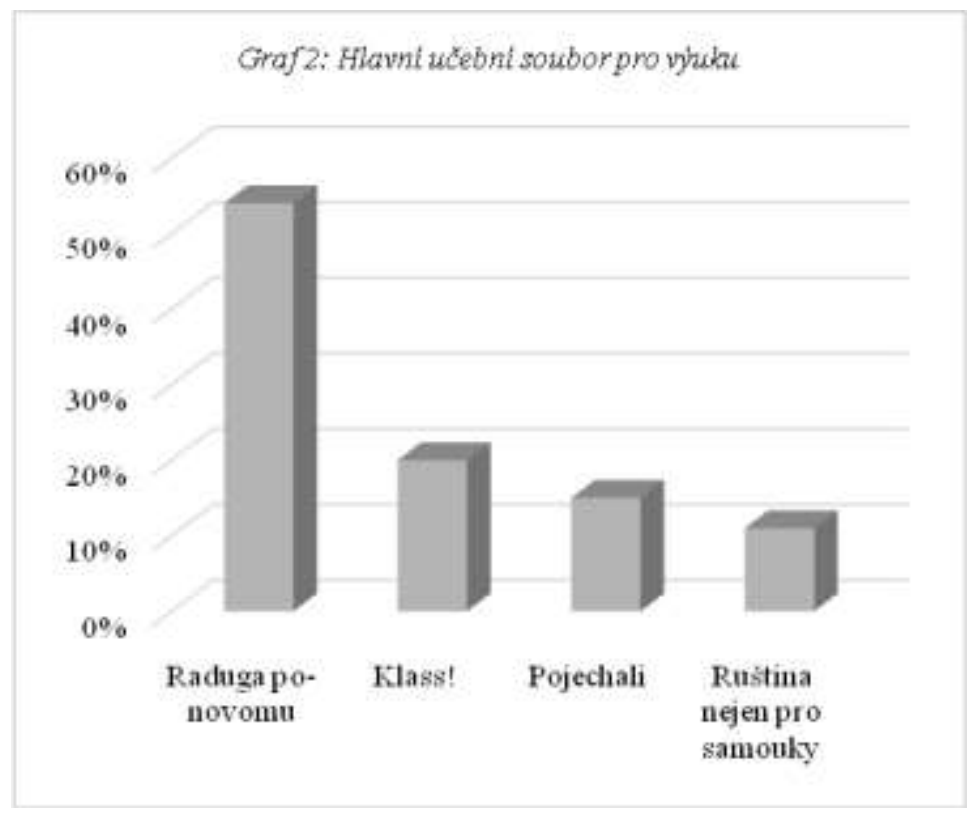

\footnotetext{
${ }^{43}$ Tuto učebnici volili pouze respondenti, kteří jako své působiště uvedli jiný typ školy, z učitelů základních a středních škol tuto učebnici neuvedl ani jeden respondent.

${ }^{44} Z d e$ přesně nelze procentuálně rozlišit jednotlivé publikace, nebot' většina respondentů uváděla tyto učebnice jako „učebnice k maturitě od Infoi“ či podobným způsobem, uvádíme proto takto souhrnně.
}

81

XLinguae Journal, Volume 10 Issue 1, January 2017, ISSN 1337-8384 
V další části dotazníku jsme zjišt'ovali, jaké klady a zápory spatřují učitelé u učebního souboru, který využívají ve své výuce jako primární zdroj, co jim u tohoto souboru chybí a proč byl jimi právě tento soubor zvolen pro výuku ruského jazyka. Otázky byly koncipovány jako otevřené a nebylo určeno, kolik kritérií mají uvádět, četnost uvádíme proto pouze jako prostý počet uvedení. Odpovědi na tyto otázky byly velmi rozmanité a do značné míry vypovídají o očekáváních, která učitelé vủči učebním souborům mají.

U učebního souboru Raduga po-novomu jsme zaznamenali celkem 36 různých kladných rysů, učitelé nejčastěji pozitivně hodnotili přehlednost $(23 x)$, systematičnost $(10 \mathrm{x})$ a dostatek cvičení $(9 \mathrm{x})$, výběr témat $(5 \mathrm{x})$ a rozvoj dovednosti čtení (4x). U negativ jsme zaznamenali dokonce 40 různých odpovědí. Nejvíce výhrad měli učitelé k textům a slovní zásobě, nedostatek slovní zásoby nebo neaktuální slovní zásobu uvedlo 8 respondenti̊, málo poslechových textů či na kvalitu jejich zpracování upozornilo 7 respondentů. Otázka, co nejvíce v souboru chybí, do značné míry korespondovala s negativy, dotazovaným nejčastěji chybí kvalitní poslechové texty (odpovídající maturitě) $-11 \mathrm{x}$ a aktuální konverzační témata $5 \mathrm{x}$. V různých variacích se také objevoval požadavek na aktuálnost a zajímavost témat či textů pro žáky. $\mathrm{Z}$ důvodů, proč byl tento soubor vybrán, dominuje fakt, že ve své době byl soubor jediný na trhu - 10x, dále pak učitelé uváděli, že byl vybrán či doporučen kolegy celkem 16x. Odpovědí, které by dokazovali, že by se př́slušný učitel u tohoto souboru zamýšlel nad různými kritérii, která by měl kvalitní učební soubor splňovat, shledáváme pouze 7 , navíc uvedených pouhými třemi učiteli, což považujeme za velmi alarmující stav.

Pozitiva učebního souboru Klass! byla vymezena v 18 různých variantách, z hodnocení vyplývá, že učitelé oceňují především modernější pojetí souboru (oproti souboru Raduga po-novomu), aktuálnost textů i témat, větší zajímavost pro studenty a také integraci učebnice a pracovního sešitu do jedné knihy, tato pozitiva učitelé uváděli také jako hlavní př́činy výběru právě tohoto učebního souboru pro svou výuku. Negativních rysů uvedli respondenti celkem 25 různých, nejčastěji se objevuje kritika nesystematického pojetí gramatiky $(10 \mathrm{x})$ a dále př́tomnost chyb a překlepů $(5 \mathrm{x})$, které by v kvalitní učebnici rozhodně být neměly. Požadavek systematického, přehledného a logicky návazného zpracování gramatiky uváděli učitelé jako základní podmínku pro zlepšení souboru. ${ }^{45}$

Na učebním souboru Pojechali! respondenti nejvíce oceňovali jeho hravost, orientaci na zájmy žáka a důraz na nácvik zvukové stránky ruského jazyka. Jako zápor byl uváděn nejhojněji nedostatek cvičení k procvičení gramatiky a slovní zásoby a nedostatek textů pro poslech a čtení s porozuměním. Učitelé by uvítali tedy nejen více cvičení a textů, ale také více reálií, př́ípadně jejich dřivější zařazení, a také více her a zábavy, což jistě vyplývá z primárního určení souboru pro žáky základní školy. Důvody, proč byl tento soubor vybrán, byly různé, nejčastěji uváděli respondenti shodné prŕčiny jako u souboru Raduga po-novomu, tedy že ve své době se jednalo o jediný soubor pro výuku ruštiny na základních školách na českém trhu, př́padně že byl vybrán či doporučen kolegy, dále pak důvody v podstatě korespondují s uvedenými pozitivy souboru.

\footnotetext{
${ }^{45} \mathrm{Je}$ zřejmé, že tohoto nedostatku si bylo vědomo i nakladatelství Klett, které vydalo v roce 2016 jako doplňující materiál Přehled základnich gramatických jevi̊ $1-3$ ke všem třem dílům souboru; kvalita tohoto materiálu je však velmi diskutabilní a vyvstává otázka, zda tento přehled může vyhovět požadavkům na systematičnost, které učitelé v dotazníku vyjadřovali.
}

82 


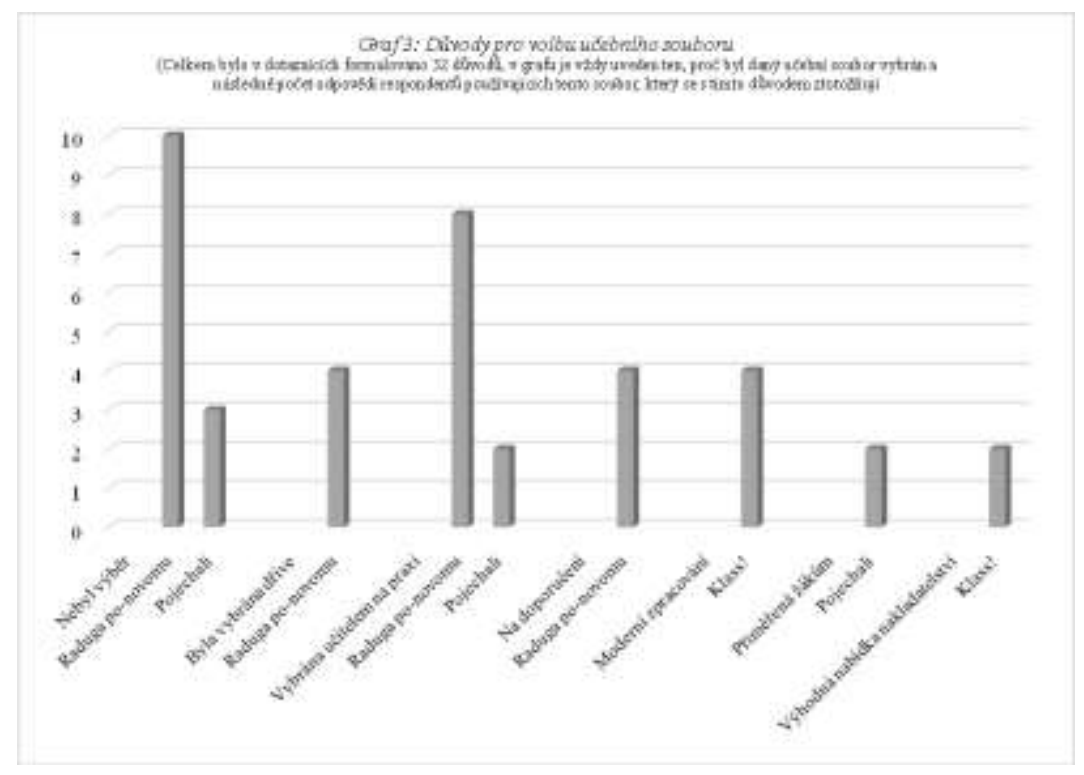

Jak již bylo uvedeno výše, učebnice Ruština nejen pro samouky je využívána $\mathrm{v}$ souladu $\mathrm{s}$ jejím primárním určením především v různých kurzech či na vysokých školách. Pozitivně shledávají respondenti především její přehledné zpracování gramatiky, dostatek cvičení k jejímu procvičení a rozsah nabízené slovní zásoby. Přehlednost gramatiky byla uváděna jako nejčastější důvod výběru právě této učebnice. Jako nejslabší rys považují dotázaní obecně zastaralost - textů i slovní zásoby. Respondenti by uvítali také lepší strukturu učebnice, doplnění učebnice o pracovní sešit a více námětů pro nácvik praktické konverzace.

Z našeho pohledu nejpodstatnější z celého dotazníku byla otázka, jaká hlediska považují učitelé při výběru učebního souboru za nejdůležitější. Uvedená četnost je opět pouze prostý počet uvedení. Celkem bylo v dotaznících uvedeno 51 různých kritérií, přičemž zcela dominují dvě, a sice přehlednost $(32 x)$ a všestranná přiměřenost žákům $(25 \mathrm{x})$. $\mathrm{S}$ těmito dvěma hledisky ale také velmi úzce souvisí i další nejčastěji uváděná kritéria - zajímavost pro žáky $(17 \mathrm{x})$, systematičnost $(13 \mathrm{x})$, aktuálnost $(13 \mathrm{x})$ a orientace na praktické využití (10x). Není překvapivé, že významným faktorem ovlivňujícím výběr, je i cena a obecně dostupnost souboru (19x). Dalšími uvedenými kritérii byly: dostatek cvičení (10x), dostatek a kvalita textů $(9 x)$, srozumitelnost pro žáky $(8 x)$, obsahová pestrost $(8 x)$, zaměření na všechny řečové dovednosti $(6 x)$, ostatní hlediska byla zmíněna méně než pětkrát. Za zajímavé zjištění považujeme fakt, že respondenti uvedli pouze dvakrát existenci nějaké formy IT podpory, ačkoli je v současné době na využívání ICT ve výuce cizích jazyků kladen silný akcent. 


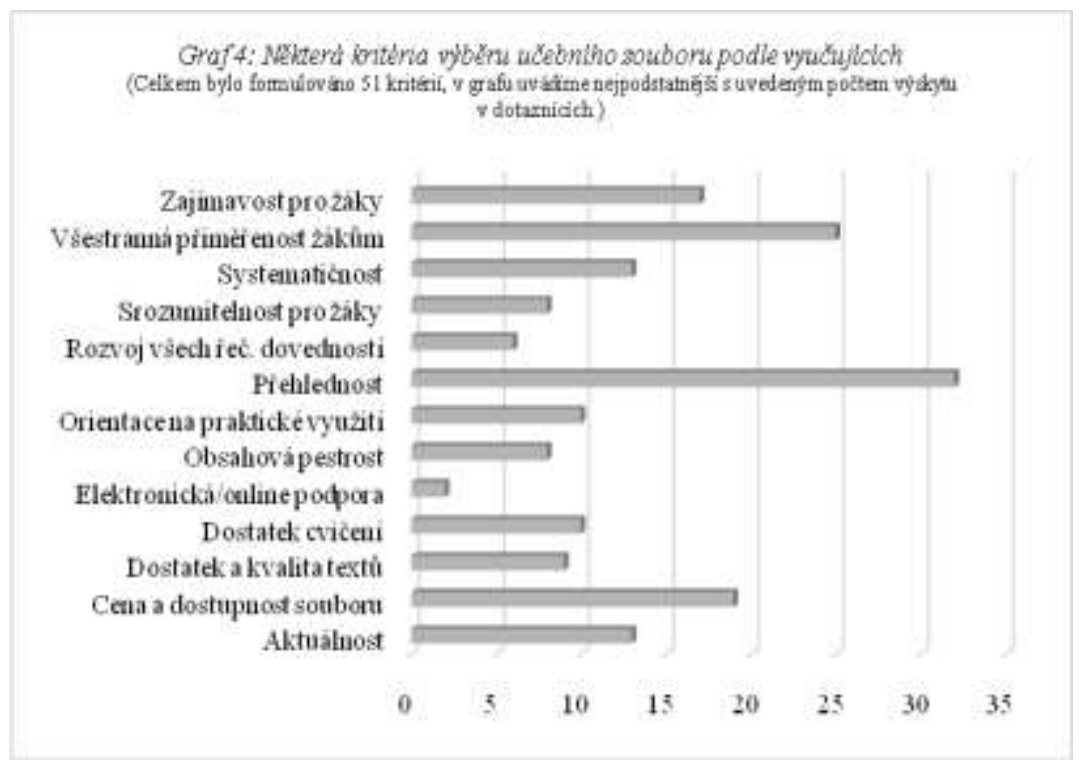

Ze všech v dotazníku uvedených kritérií je patrné, že učitelé mají často velmi různá očekávání a shledávají jako nejpodstatnější aspekty odlišné, což jistě do značné míry souvisí nejen s cíli výuky a příslušnou žákovskou skupinou, ale i s osobností učitele, který i nadále sehrává v cizojazyčné výuce klíčovou úlohu, a to nejen v souvislosti s výběrem učebních materiálů.

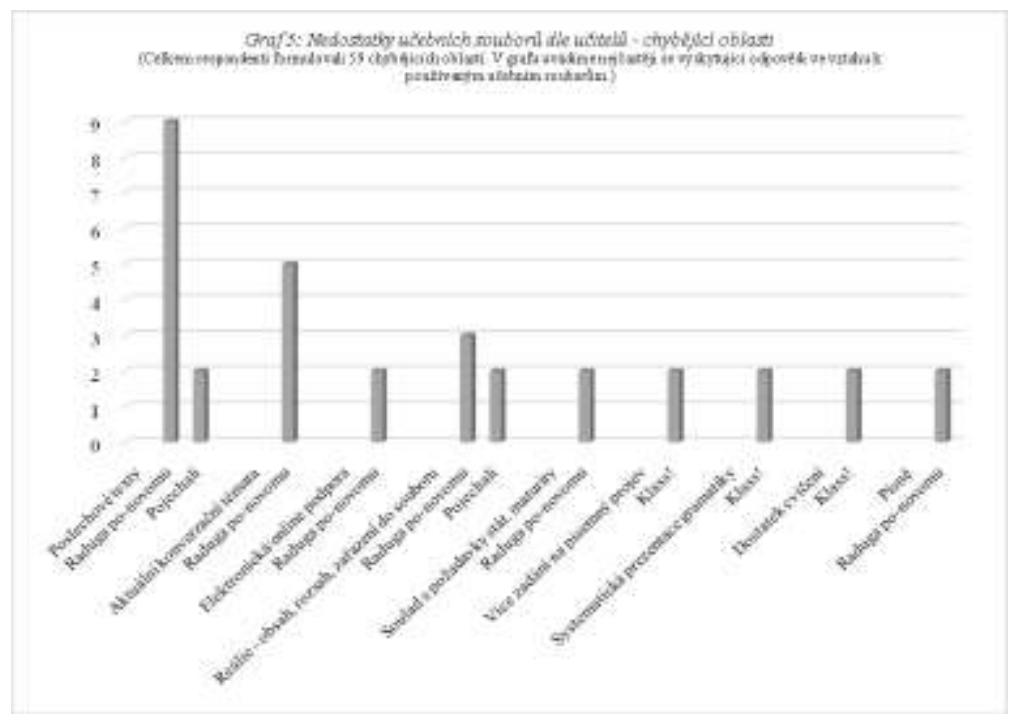

Závěr

Ačkoliv v současné době moderní technologie výrazným způsobem ovlivňují vzdělávací proces, učební soubor s tištěnou učebnicí jako jeho hlavním 
komponentem je stále legitimním didaktickým prostředkem a významným faktorem ovlivňujícím práci žáků i učitelů. Jak jsme se pokusili naznačit v krátkém historickém exkurzu, potýká se současná česká didaktika ruštiny jako cizího, resp. jako dalšího cizího jazyka (viz údaje ze statistické ročenky výše) s problémy, které trápily didaktiky západních jazyků na počátku 90. let. Při snaze nalézt řešení problémů je třeba zohlednit současný stav (výuka ruštiny jako dalšího cizího jazyka po angličtině a silný vliv češtiny jak v podobě kladného přenosu, tak i interference) a možnosti dané personální situací na všech úrovních (rozvoj oboru v rovině vědecké, reálná situace ve školách).

O významu učebního souboru svědčí také celá řada obecně- i oborovědidaktických definic, $\mathrm{z}$ nichž některé jsme pro představu uvedli v první části textu. Dále byla pozornost věnována také vztahu vyučujících $\mathrm{k}$ učebnici. Ve druhé části článku se již konkrétně zabýváme výběrem učebnice ruštiny a faktory, který tento důležitý proces ovlivňují. Formulovali jsme 11 oblastí, které je třeba reflektovat při posuzování a hodnocení jednotlivých učebních souborů a následném výběru - praxe ukazuje, že vyučující, kteří při volbě učebního souboru například podlehli lákavým nabídkám vydavatelství či vybrali soubor pouze na základě prvního dojmu, se následně potýkají s výraznými problémy, které význačně ovlivňují jak výuku, tak i výsledky žáků.

Následně byly $\mathrm{v}$ textu představeny výsledky dotazníkového průzkumu provedeného u 96 vyučujících ruského jazyka. Výsledky první části dotazníku ukazují, do jaké míry jsou vyučující ruského jazyka seznámeni s aktuální nabídkou učebních souborů pro výuku ruského jazyka na českém trhu. Ukazuje se, že zatímco „tradiční“ učební soubory Raduga po-novomu a Pojechali, dnes již také Klass znají téměř všichni dotazovaní, o novinkách či nepř́liš často používaných titulech ví jen část z nich. Zbývající otázky v dotazníku byly záměrně koncipovány jako otevřené. Naší snahou bylo nechat vyučující formulovat vlastními slovy myšlenky, a to mj. s cílem zjistit, do jaké míry jsou tito lidé (s praxí mnohdy delší než 20 let) schopni hlubší reflexe. Zjištění bohužel ukazují, že „vymanit se z role běžného konzumenta“ dokáže pouze menší část $\mathrm{z}$ nich $-\mathrm{v}$ odpovědích většiny respondentů bylo reflektováno pouze minimum $\mathrm{z}$ uvedených 11 kritérií, $\mathrm{k}$ nimž bychom měli při výběru tak závažného a důležitého didaktického prostředku přihlížet.

\section{Bibliograpic references}

BERDICHEVSKIJ, A.L. - GOLUBEVA, A.V. 2015. Kak napisat mezhkulturnyj uchebnik russkogo jazyka kak inostrannogo. Sankt-Peterburg: Zlatoust. ISBN 978-586547-843-0

HENDRICH, J. 1993-1994. Rozlisujme pozorne a dusledne. In: Cizi jazyky, vol. 37, n. 3-4, pp. 81-82. ISSN 1210-0811

HOUSKA, L. 1994-1995. Ucebnice nase, nebo zahranicni?. In: Cizi jazyky, vol. 38, n. 7-8, pp. 270-272. ISSN 1210-0811

JELINEK, S. 1994-1995. K funkeni charakteristice ucebnic cizich jazyku. In: Cizi jazyky, vol. 38, n. 3-4, pp. 83-88. ISSN 1210-0811

KALHOUS, Z. - OBST, O. et al. 2002. Skolni didaktika. Praha: Portal. ISBN 807178-253-X

KNECHT, P. - JANIK, T. et al. 2008. Ucebnice z pohledu pedagogickeho vyzkumu. Brno: Paido. ISBN 978-80-7315-174-4.

KONECNY, J. 2012. Vyznam a uloha ucebnice při formovani foneticke gramotnosti. In: Gramotnost ve skole: Sbornik z konference poradane 28.-29.3.2012. Hradec Kralove: Pedagogicka fakulta Univerzity Hradec Kralove. ISBN 978-80-905245-0-7.

KONECNY, J. 2013a. Analyza ucebnich souboru pro stredni skoly z hlediska utvareni foneticke gramotnosti ceskych zaku v ruskem jazyce. In: Prazska rusistika 2013: recenzovany sbornik prispevku z konference konane dne 18. dubna 2013 
v Praze. Praha: Pedagogicka fakulta Univerzity Karlovy, 2013, pp. 123-130. ISBN 978-80-7290-634-5.

KONECNY, J. 2013b. Obucheniye russkomu jazyku v Cheshskoy shkole. In: Teoriya i praktika formirovaniya kommunikativnoj kultury : Tradicii i innovacii: materialy III Mezhdunarodnoj nauchno-prakticheskoj konferencii 18 aprelya $2013 \mathrm{~g}$. Novokuzneck: RIO KuzGPA. pp. 119-124. ISBN 978-5-85117-732-3.

KONECNY, J. 2016. Sovremennye UMK po russkomu jazyku kak inostrannomu dlja nachalnykh shkol $\mathrm{v}$ Chekhii. In: Aktualnyje problemy kommunikativnogo obrazovanija v 21 veke: sbornik naučnych statej po materialam VII mezhdunarodnoj nauchno-prakticheskoj konferencii. Novokuzneck: RIC NFI KemGU. pp. 121-126. ISBN 9785-91797-153-7.

MANAK, J. - KLAPKO, D. (ed.) 2006. Ucebnice pod lupou. Brno: Paido. ISBN 807315-124-3.

MANAK, J. - KNECHT, P. (eds.) 2007. Hodnoceni ucebnic. Brno: Paido. ISBN 97880-7315-148-5.

ISBN 80-7041-174-0

PRUCHA, J. 2005. Moderni pedagogika. Praha: Portal. ISBN 80-7367-047-X

PRUCHA, J. 1999. Vzdelavani a skolstvi ve svete: zaklady mezinarodni komparace vzdelavacich systemu. Praha: Portal. ISBN 80-7178-290-4

PURM, R. 1998. Individualizace vyucovani a ucebnice ciziho jazyka. In: Cizi jazyky, vol. 41, n. 7-8, pp. 111-112. ISSN 1210-0811

PURM, R. - JELINEK, S. - VESELY, J. Didaktika ruskeho jazyka: vybrane kapitoly. 2003. Hradec Kralove: Gaudeamus. PYCHOVA, I. 1993-1994. Moda a ucebnice cizich jazyku. In: Cizi jazyky, vol. 37, n. 3-4, pp. 104-109. ISSN 1210-0811

SIKOROVA, Z. 2004. Vyber ucebnic na zakladnich a strednich skolach. Ostrava: PdF OU. ISBN 80-7042-373-0.

Statisticke rocenky skolstvi: vykonove ukazatele (online). Dostupne z: http://toiler.uiv.cz/rocenka/rocenka.asp

RADA EVROPY. 2002. Spolecny evropsky referencni ramec pro jazyky. Olomouc: UP. ISBN 80-244-0404-4.

SKALKOVA, J. 2007. Obecna didaktika. Praha: Grada. ISBN 978-80-247-1821-7

STUCHLIKOVA, I. - JANIK, T. et al. 2015. Oborove didaktiky: vyvoj - stav perspektivy. Brno: Masarykova univerzita. ISBN 978-80-210-7884-0

ZOFKOVA, H. 1989. Metodologicka vychodiska k analyze ucebnich osnov a ucebnic jazyku. In: Pedagogika : casopis pro pedagogickou theorii a praxi, vol. 39, n. 2, pp. $155-165$.

Článek je výstupem projektu 236065-1672 Inovace výuky didaktiky ruského jazyka na katedre rusistiky a lingvodidaktiky Pedagogické fakulty Univerzity Karlovy.

Words: 5110

Characters: 38957 (21, 64 standard pages)

PhDr. Lenka Rozboudova, Ph.D.

PhDr. Jakub Konecny, Ph.D.

Head of Russian \& Language Teaching Methodology Department

Charles University - Faculty of Education

Magdaleny Rettigove 4, 11639 Prague

Czech Republic

lenka.rozboudova@pedf.cuni.cz

jakub.konecny@pedf.cuni.cz 